\title{
Discovering digital cultural capital in London's events of art and technology: reviewing the last decade
}

\author{
Alicia Bastos \\ London College of Communication \\ University of the Arts London \\ 8 Sanford Walk London SE14 6NB \\ http://www.aliciabastos.com lix@aliciabastos.com
}

\begin{abstract}
This paper is based on a five years' research focused on the measurement of cultural contribution of events of art and technology to London. Developing the concept of 'cultural capital' devised by sociologist Pierre Bourdieu, it was possible to identify their 'forms', such as 'embodied', 'objectified' and 'institutionalised' as parameters to a cultural measurement system. Applying this system to evaluate the cultural potential of events of art and technology brings the 'cultural capital' concept to the 'digital age' and results in the discovery of 'digital cultural capital'. The objective is to find out how much these events can contribute to cultural arts organisations and venues, artists and curators as much to the public experience. For this evaluation, London's most important events of art and technology were identified and analysed through case studies and interviews with specialists in the field.
\end{abstract}

Digital cultural capital. London's events of art and technology.

\section{INTRODUCTION}

As technology revolutionises people's lives, the creative arts are challenged to question their concepts, purposes and values. These changes test the creative industries and play a major part in translating the cultural development of the digital age. A growing trend of art and technology events is becoming noticeable, from the underground culture to the mainstream, on a global level, most visible in multicultural cities around the world.

The importance of London in the international artistic field is one of the most influential creative hubs in the world. The case of London, with arts and technology events, travels from being a pioneer in underground experiments, pole of 'avant-garde' artists, through waves of hope and disappointments. However, within the last ten years, because of the digital revolution, events of art and technology are gaining public popularity, invading alternative spaces as well as major art venues and cultural spaces.

This paper evaluates the cultural contribution of art and technology events in London. Firstly, the sociological concept of 'cultural capital' is unfolded, revealing powerful measurement system parameters. Secondly, the explanation of what are here considered events of art and technology will lead to identify their key aspects. Finally, the analysis of these keys aspects using the 'cultural capital' parameters result in discovering the 'digital cultural capital' of these events.

This is a moment when artistic and cultural projects and organisations must incorporate technology, not only in their administrative and marketing processes but also in their creative content. The relevance of this paper is to increase knowledge of the management of the creative arts, so that practitioners and managers can understand the impact of the changes of technology in the arts and discover the opportunities that come with them.

This evaluation comes out with arguments for the practical application of these events in London's cultural and arts organisations, councils and schools and consequently influencing the Creative Industries.

\section{THE CULTURAL ISSUES}

The first section briefly introduces the concept of 'cultural capital' from Pierre Bourdieu (1986), explaining where a 'cultural measurement system' can be found within. It also explains what is to be 
considered 'digital cultural capital', in order to understand the power of culture in the digital age. The objective is to identify a conceptual framework of culture measurement that is applicable in the 'digital age'.

\subsection{Cultural capital and the cultural measurement system}

'Cultural capital' is a concept created by Pierre Bourdieu in the early 1970s, as an attempt to measure how cultural values and the possession of resources can cause social class differences (Bourdieu, 1986). This concept raised several arguments in the academic field, contesting that use of the word 'capital' may have lead to misunderstanding the purpose of the concept. However, Bourdieu (1986), when explaining the applications of different forms of capital, mentioned clearly, in a parenthesis, that capital was a word used to describe power.

\begin{abstract}
Cultural capital can exist in three forms: in the embodied state, i.e., in the form of long-lasting dispositions of the mind and body; in the objectified state, in the form of cultural goods (pictures, books, dictionaries, instruments, machines, etc.)... And in the institutionalised state, a form of objectification which must be set apart because, as will be seen in the case of educational qualifications, it confers entirely original properties on the cultural capital which it is presumed to guarantee. (Bourdieu, 1986, p. 243)
\end{abstract}

If it is possible to measure social class stratification through the evaluation of cultural power through 'embodied', 'objectified' and 'institutionalised' forms, it is possible to use the same parameters to measure cultural levels in different areas.

\subsection{Digital cultural capital}

The capital generated from digital cultural production may well be described as digital cultural capital. Therefore, the concept arises from the merging of digital culture and cultural capital. The challenge is now to discover if Bourdieu's forms of cultural capital (1986) can be used to measure culture in the digital age. It is essential to highlight the importance of digital gadgets as objectified cultural capital, to point out that the shift of talent and process of audience participation in cultural knowledge production can embody culture and to demonstrate how educational institutions are dealing with these transformations in learning.

Art and cultural production are responding to the technological revolution, especially in the visualisations and experience of the arts. All these changes are making a huge impact on the 'creative industries' in powerful sectors such as photography, films and music from their production until distribution. The possession of cultural values has changed, and from an artistic perspective, what differs is how the culture is acknowledged, and how cultural information is shared.

Applying Bourdieu's forms of 'cultural capital', it is possible to identify the parameters used to discover the 'digital cultural capital':

- 'Embodied': referring to the mind and body meaningful artistic talent, empowerment through culture development.

- 'Institutionalised': education in the arts has changed, and so has its relevance to the professional market that will produce cultural content.

- 'Objectified': referring to cultural goods, computers and creative mobile gadgets, which are the biggest disseminators of culture and producers of contemporary life.

\section{EVENTS OF ART AND TECHNOLOGY}

Art and technology has become a major field of contemporary sociological and technical research. However, these events have not yet been studied with a focus on their cultural contribution. This section analyses events of art and technology, identifying their key aspects of event production such as curatorship and artistic collaborations, questions about venues and virtual spaces, the relationship with a growing audience and examples of art that can be included in these events.

\subsection{What are events of art and technology?}

The revolution of technology in the arts is told in the history of events where artists have expressed themselves using various technological media in exhibitions, art shows and through artistic movements. The visualisations of the arts play a very influential role in this technological revolution, allowing a superior level of artistic expression and public experience. Events of art and technology can be festivals, performances, exhibitions, art fairs, conferences and collaborations. In the academic discussions this arts style has been called digital art, interactive arts, multi-media or computer arts.

Lately, technology has created an umbrella of art forms that use emergent media, platforms and digital tools. Examples are 2D or 3D computer designs called digital imaging, digital photography, sculpture, digital installations and virtual realities, Net Art (meaning internet art, also called web-art), performance, sound art and electronic music, digital animation and video, software, databases, interactive systems, projections and game art (Wands, 2006). 
Graham (2007) reminds us that as much as an art movement can be loose and ever changing, the revolution of technology in the arts needs to be documented, and he argues that public events are key in understanding the history of any movement.

\subsection{Key aspects of events of art and technology}

The importance of identifying events of art and technology's aspects is in finding measurable fields where the level of culture can be evaluated.

- Multidisciplinary talent: shift of talent from handcraft artists to scientists, engineers, designers and other disciplines.

- Audience participation: change of audience perspective and participation contrast with conventional art events and organisations, where the audience is passive and subjected to the major influence of curators.

- Education: use of technological tools to produce artworks and the educational characteristics of events of art and technology to relate with the public.

- Production of digital cultural content: growing content production using digital tools and platforms, specialised magazines, books and academic works of research on this area.

- Venue and curation issues: new curatorship area, difficult ingression in the major art venues, high budgets for exhibitions.

- Funding and corporate sponsorship: there is great potential for corporate sponsorship from media and communication creative businesses. Also, funding agencies are considering arts and technology events, especially ones that contribute to educational programmes.

\section{LONDON'S EVENTS OF ART AND TECHNOLOGY}

This section will introduce a brief history of events of art and technology in London, focusing on and illustrating the last decade. Also a table will show the challenges that face events of art and technology in London.

\subsection{History of events of art and technology in London}

The history of art and technology events began in the 20th century when computers were created at the beginning of the 'digital age' (Wands, 2006), creating a major influence in the creation and experience of arts. Rush (1999) refers to key art movements such as the Futurists in the early 20th century, who were already using technological inspiration for traditional media such as painting and sculpture, changing the arts' visualisations, and introducing sounds resulting from experiments with machines.

Fluxus, which was an artists' collective experimenting with multimedia in art performances, held events internationally and in London between 1962 and 1978. Both movements were happening in different places in the world around the same time (Rush, 1999).

Cybernetic Serendipity, the first art and technology exhibition in London at the Institute of Contemporary Arts in 1968, mixed the work of scientists and artists (Gere, 2004). And in 1969, the Computer Arts Society (CAS) promoted Event One, an exhibition about 'creative use of computers in the arts' at the Royal College of Art (Mason, 2009).

When exploring the importance of new media art events and 'digital cultural capital' in London, it is crucial to understand the changes that the UK government's Digital Britain report has made to the 'creative industries'. The UK government in the last ten years has published a considerable number of documents and reports, and has conducted public surveys about the relevance of the arts and culture.

The Creative Industries Mapping was a document was published in March 1998 and March 2001, by the Department for Culture, Media and Sports (DCMS), containing specific information about thirteen industries across the whole of the UK. This document inspired other cultural cities around the world (O'Connor, 2007). Since 2005, Taking Part, an audience survey created by the DCMS, has collected annual data concerning engagement in culture, leisure and sport to inform public sector bodies such as the Arts Council. Creative Britain was published in February 2008, positioning the 'creative industries' at the heart of the economy and showing Greater London to have the highest concentration of arts and music specialist schools in the UK. This document also includes a whole chapter supporting research and innovation, with the aim of exploring opportunities for the new technologies.

\subsection{The last decade 1999-2009}

In the last ten years in London several events were created including a digital and new media arts, most of them relevant to the evolution of the visualisation of arts.

To understand why London has an interesting history of events of art and technology, it is important to visualise the main events of the past ten years. This timeline contains the main events of art and technology in art venues and independent organisations. 


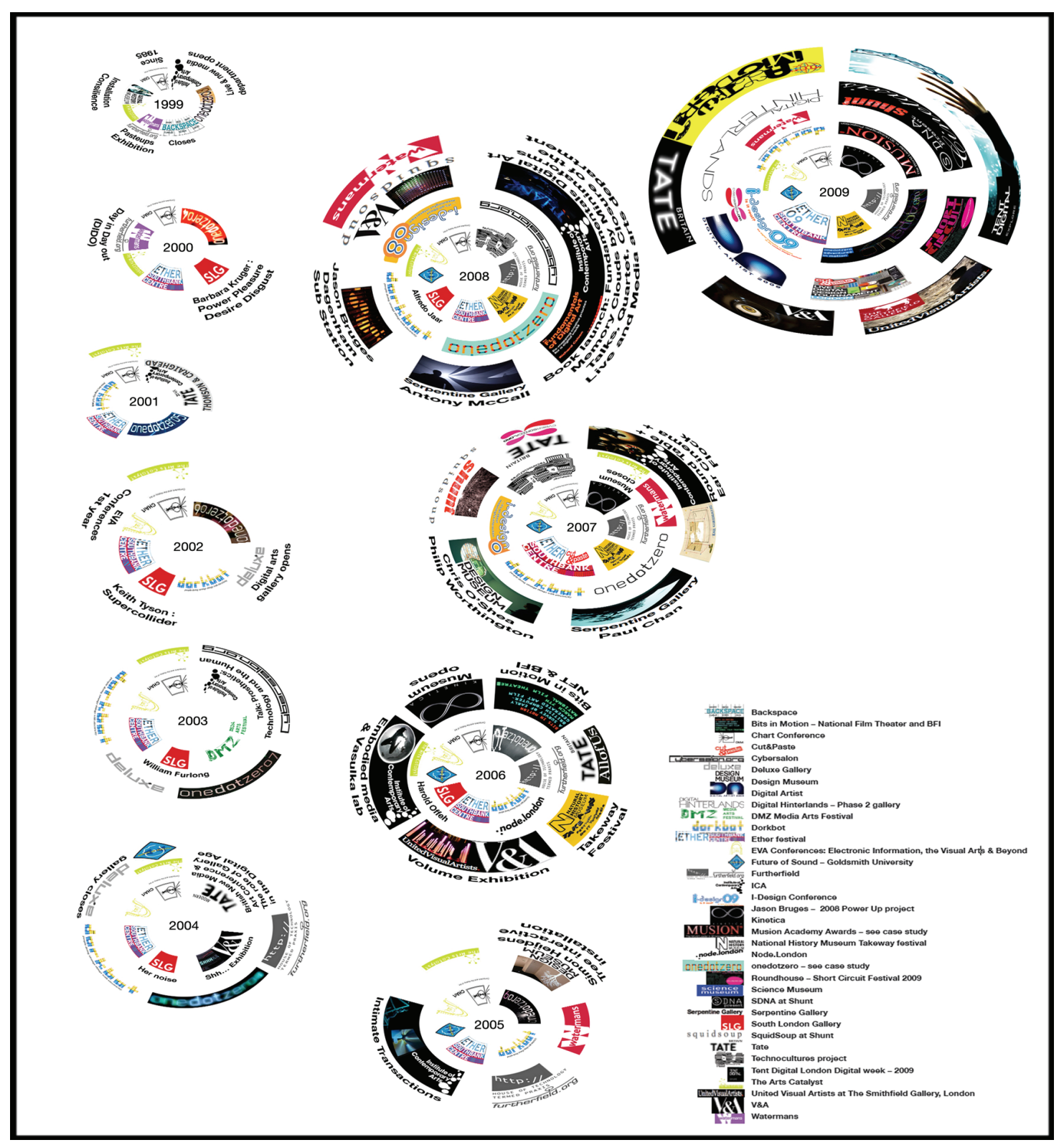

Figure 1: Timeline of events of art and technology in London 1999-2009 


\subsection{Issues}

Case studies of events of art and technology in London such as 'onedotzero' and 'Kinetica Art Fair', plus eleven interviews with key informants including university professors, media art curators, artists, technologists, music programmers and event organisers in London, are included in the main research on which this paper is based. The table below presents challenges from the creation and production of events of art and technology in the major art venues and alternative spaces in London.

Table 1: Key aspects of events of art and technology issues

\begin{tabular}{|c|c|}
\hline Key aspects & Issues \\
\hline Multidisciplinary talent & 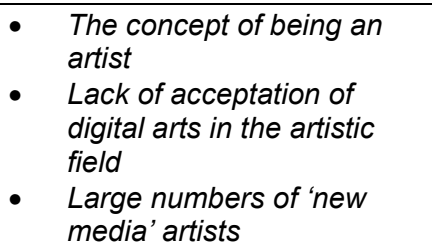 \\
\hline Audience participation & $\begin{array}{l}\text { - } \quad \text { The public is looking for } \\
\text { more interactive ways to } \\
\text { experience arts } \\
\text { - } \quad \text { Copyrights issues } \\
\text { - } \quad \text { Lack of public recognition } \\
\text { to arts that use new } \\
\text { medium }\end{array}$ \\
\hline Education & $\begin{array}{l}\text { - } \quad \text { Lack of public technologic } \\
\text { education } \\
\text { - Large number of new } \\
\text { students in the field of art } \\
\text { and technology }\end{array}$ \\
\hline $\begin{array}{l}\text { Production of digital } \\
\text { cultural content }\end{array}$ & $\begin{array}{ll}- & \text { Copyrights issues } \\
\text { - } & \text { Vast expansion of digital } \\
\text { artistic content crossing } \\
\text { with media creative content }\end{array}$ \\
\hline $\begin{array}{l}\text { Venue and curation } \\
\text { issues }\end{array}$ & $\begin{array}{ll}\text { - } & \text { High competition for } \\
\text { exhibition space in major } \\
\text { art venues } \\
\text { - High budgets for set up and } \\
\text { maintenance } \\
\text { - Small number of } \\
\text { specialised curators } \\
\text { - Traditional thinking of arts } \\
\text { curation } x \text { artistic } \\
\text { innovation }\end{array}$ \\
\hline $\begin{array}{l}\text { Public funding and } \\
\text { corporate sponsorship }\end{array}$ & $\begin{array}{l}\text { - High budgets for event's } \\
\text { production } \\
\text { - Low support and } \\
\text { understanding from funding } \\
\text { public agencies } \\
\text { Artistic image is judged } \\
\text { under corporate } \\
\text { sponsorship. }\end{array}$ \\
\hline
\end{tabular}

\section{DISCOVERING 'DIGITAL CULTURAL CAPITAL' IN EVENTS OF ART AND TECHNOLOGY}

To evaluate properly what is the cultural impact that public events of art and technology can have, it is essential to link the key aspects of those events with the three types of 'cultural capital' by Bourdieu (1986).

'Cultural capital' has inspired different perspectives of cultural analysis, such as the examination of sub-culture by writer ST (Thornton, 1995), who investigated club culture through youth culture in and around 1994 in London. Digital technologies were part of the subculture of young people. But they have now become the mainstream vehicle of communication, and a powerful creative tool. Because art has also been incredibly affected by the digital revolution, the impact of cultural changes through the arts needs to be evaluated.

Adapting the three types of 'cultural capital' to 'digital cultural capital' makes it possible to evaluate new media art events through their key aspects. The objective is to discover how these events can contribute to culture and to use this discussion for the practical application and management of art and technology events in London.

Table 2 below illustrates how types of 'cultural capital' were identified in the findings, and how they are connected. 
Table 2: Applying the 'measurement system' using cultural capital forms to evaluate the keys aspects of art and technology events, identifying 'digital cultural capital'.

\begin{tabular}{|c|c|c|c|}
\hline \multirow[t]{2}{*}{ Key aspects } & \multicolumn{3}{|c|}{ Levels of ' digital cultural capital' } \\
\hline & Embodied & Institutionalised & Objectified \\
\hline Multidisciplinary talent & $\begin{array}{ll}\text { - } & \text { Larger possibilities for } \\
& \text { artistic talent expression } \\
\text { - } & \text { Easy access to digital } \\
& \text { creative tools } \\
\text { - } & \text { Artistic collaboration } \\
\text { - } & \text { Diversity }\end{array}$ & $\begin{array}{ll}\text { - } & \text { Cross-discipline } \\
\text { events }\end{array}$ & $\begin{array}{l}\text { Artists are working in } \\
\text { different mediums and } \\
\text { collaborating through } \\
\text { the world wide web }\end{array}$ \\
\hline Audience participation & $\begin{array}{ll}\text { - } & \text { Multi-sensorial experience } \\
\text { - } & \text { Interaction } \\
\text { - } & \text { Active artistic experience } \\
\text { - } & \text { People interested in } \\
& \text { technology feel closer to } \\
& \text { the arts }\end{array}$ & $\begin{array}{l}\text { - } \\
\text { Artistic digital } \\
\text { interaction is a new } \\
\text { field and growing of } \\
\text { research in the } \\
\text { academia. } \\
\text { Sharing learning } \\
\text { experience in events. }\end{array}$ & $\begin{array}{l}\text { Easier access to the } \\
\text { arts experience } \\
\text { (computer arts) } \\
\text { Easy access to digital } \\
\text { creative tools }\end{array}$ \\
\hline Education & $\begin{array}{ll} & \text { Skills exchange } \\
\text { - } & \text { Talks and workshops } \\
\text { - } & \text { The improvement of the } \\
& \text { public experience of art. }\end{array}$ & $\begin{array}{ll}\text { - } & \text { Revolution of the } \\
\text { artistic education } \\
\text { system } \\
\text { - Involvement of } \\
\text { different educational } \\
\text { organisations } \\
\text { Growth of academic } \\
\text { works about art and } \\
\text { technology } \\
\text { Educational events } \\
\text { through talks and } \\
\text { workshops } \\
\end{array}$ & $\begin{array}{l}\text { Books, magazines and } \\
\text { DVDs about art and } \\
\text { technology } \\
\text { - Educational material } \\
\text { produced by events }\end{array}$ \\
\hline $\begin{array}{l}\text { Production of digital } \\
\text { cultural content }\end{array}$ & $\begin{array}{ll}- & \text { Freedom of opinion } \\
\text { expression through arts } \\
\text { and technology } \\
\text { - } \quad \text { Easy access to digital } \\
\text { creative information such } \\
\text { as software tutorials } \\
\text { - } \quad \text { Artistic collaboration } \\
\text { - Diversity }\end{array}$ & $\begin{array}{l}\text { Educational material } \\
\text { produced by the } \\
\text { events } \\
\text { Competitions that } \\
\text { incentive the } \\
\text { production of digital } \\
\text { artistic content }\end{array}$ & $\begin{array}{l}\text { Growing numbers of } \\
\text { literature from } \\
\text { academic level to } \\
\text { commercial } \\
\text { magazines. } \\
\text { Traditional art to be } \\
\text { transferred to digital } \\
\text { media for } \\
\text { documentation and } \\
\text { easier access } \\
\end{array}$ \\
\hline Venue and curation & $\begin{array}{l}\text { - Changes in the relationship } \\
\text { between arts organisations } \\
\text { and the public }\end{array}$ & $\begin{array}{l}\text { - } \text { Alternative spaces for } \\
\text { exhibition } \\
\text { - } \quad \text { The opportunity to } \\
\text { add value to the } \\
\text { exhibitions through } \\
\text { talks and workshops } \\
\text { and online } \\
\text { information } \\
\text { - Innovative ideas for } \\
\text { the experience of the } \\
\text { arts }\end{array}$ & $\begin{array}{l}\text { - Exhibitions } \\
\text { publications and } \\
\text { DVDs. } \\
\text { New art in various } \\
\text { medium for } \\
\text { collections. }\end{array}$ \\
\hline $\begin{array}{l}\text { Public funding and } \\
\text { corporate sponsorship }\end{array}$ & $\begin{array}{l}\text { - } \quad \text { Closer relationship of } \\
\text { consumer/brand } \\
\text { Motivation for businesses } \\
\text { to act on social } \\
\text { responsibility through } \\
\text { promoting public events }\end{array}$ & $\begin{array}{l}\text { Creative technology } \\
\text { business getting } \\
\text { involved in } \\
\text { educational projects } \\
\text { and events through } \\
\text { the arts } \\
\text { Growing UK } \\
\text { government support } \\
\text { to events that } \\
\text { incorporate } \\
\text { educational values }\end{array}$ & $\begin{array}{l}\text { - Public art } \\
\text { commissions interest } \\
\text { in art and technology }\end{array}$ \\
\hline
\end{tabular}




\section{CONCLUSION AND RECOMMENDATIONS}

Art and technology exist in an evolving relationship that has a relevant history since the 1960s in London and which affects the way arts are created and experienced.

The inclusion of technology in the arts has expanded communication, accessibility and creativity. Art now has the freedom to express messages with and without the curation of art galleries, to include social critiques and to encourage public discussion. Moreover, technology in the arts has made possible the creation of immersive adventures on a par with the physical level of experiencing arts and increased audience participation.

With the development of digital technologies and the expansion of communication on a global level, the way people produce and consume culture is going through radical changes. London, as a multicultural metropolis, is going through a digital revolution, confirmed by the UK's government report Digital Britain. The UK government is taking action to use new technologies to improve the 'creative industries', the second largest industry in terms of internal revenue.

These kinds of events are responsible for the history of arts and technology, and include public exhibitions and installations, live performances, talks and conferences. Their key aspects expose powerful arguments which are measurable and a real cultural contribution to the people and history of London's art.

'Digital cultural capital' refers to cultural assets that people acknowledge from digital culture as identified in Table 2. Culture, especially in the digital age, is something that people can process more than possess. Events of art and technology are a potential means by which arts and cultural organisations can manage art and technology, attracting larger audiences that can participate and enjoy a social experience through the arts.

The last objective is to give arts and cultural organisations recommendations about potential opportunities that technology can bring to the arts, and the possibility of motivating a more conscious style of arts management, based on the social responsibilities that culture can offer through new media art events.

Recommendations for students, arts and cultural organisations, and the London government are:

- Research the audience-specific relationship with arts and technology and analyse the impact of digital influence in the arts sector.
- Promote the education of the relevance of media in the arts, as a powerful way of communicating a message to the public and audiences.

- Liaise with creative businesses, schools, and cultural and arts organisations to educate people in arts and technology, through publications, talks, workshops, seminaries and conferences.

- Produce new media art events in major art organisations, documenting their attendance growth and public interest and response, so that a dedicated media art venue could be created in partnership with a major gallery or museum.

\section{REFERENCES}

Bourdieu, P. (1986) The Forms of Capital. In: Richardson, J. G. (ed.) Handbook of Theory and Research for the Sociology of Education. Greenwood Press, New York. pp. 241-258. http://www.marxists.org/reference/subject/philosop hy/works/fr/bourdieu-formscapital.htm\#n2 (10 August 2009)

Creative Industries Mapping $(1998,2001)$ Department for Culture, Media and Sports (DCMS). http://www.culture.gov.uk/reference library/publicat ions/4632.aspx (27 August 2009)

Digital Britain: Creating the Skills for the Digital Economy: A summary of recommendations for action. (2009) E-skills U.K. \& Skillset, London. http://www.culture.gov.uk/reference library/publicat ions/6071.aspx (3 July 2009)

Gere, C. (2004) New Media Art and the Gallery in the Digital Age. Tate Papers. London.

http://www.tate.org.uk/research/tateresearch/tatepa pers/04autumn/gere.htm (13 August 2009)

Graham, B. (2007) Redefining Digital Art: Disrupting Borders. In: Cameron, F. \& Kenderdine, S. (eds.) Theorizing Digital Cultural Heritage. MIT Press, Massachusetts. pp. 93-111.

Mason, C. (2009) The fortieth anniversary of Event One at the Royal College of Art. EVA London 2009 Electronic visualisation and the arts. BCS, London. pp. 117-128.

O'Connor, J. (2007) The Cultural and Creative Industries: a review of the literature. Creative Partnerships. Arts Council England.

Rush, M. (1999) New media in late 20th-Century Art. Thames \& Hudson Ltd., London.

Thornton, S. (1995) Cultures: Music, Media and Subcultural Capital. Polity, London.

Wands, B. (2006) Art of the Digital Age. Thames \& Hudson Ltd., London. 